\title{
Vennootschappelijke medezeggenschap onder druk
}

\author{
Sluit de structuurregeling nog aan op de economische \\ werkelijkheid?
}

H. van Roosmalen \& H. Koster

\section{$1 \quad$ Inleiding}

Het adagium van medezeggenschap, dat 'zij de zeggenschap volgt', ligt ten grondslag aan de in 1971 ingevoerde structuurregeling. Het doel dat destijds met deze regeling werd nagestreefd, betrof het verschaffen van een stem aan werknemers op het hoogste niveau binnen de onderneming. Dit ook omdat de beleving was dat de algemene vergadering in veel gevallen te weinig tegenwicht kon bieden aan het bestuur. ${ }^{1}$ De structuurregeling moest voorzien in de groeiende behoefte aan vennootschappelijke medezeggenschap. De almaar voortschrijdende internationalisering in het (Nederlandse) bedrijfsleven heeft er echter toe geleid dat de structuurregeling niet meer aansluit op de economische werkelijkheid. Deze huidige economische werkelijkheid, die zich wat grote ondernemingen betreft vaak kenmerkt door (internationale) concernvorming, heeft geleid tot de (gedeeltelijke) teloorgang van de vennootschappelijke medezeggenschap in Nederland. In dat kader stellen wij vast dat multinationale ondernemingen zich in toenemende mate hebben verwijderd uit de invloedssfeer van vennootschappelijke medezeggenschap in Nederland. In paragraaf 2 benaderen wij de totstandkoming van en de gedachte achter de vennootschappelijke medezeggenschap in Nederland. Daarna schetsen wij in paragraaf 3 het juridisch kader. Daar komt aan de orde wanneer de structuurregeling precies van toepassing is. Ook is er enige aandacht voor rechtsvergelijking met het Duitse recht. In paragraaf $4 \mathrm{t} / \mathrm{m} 6$ beantwoorden wij de vraag in hoeverre het vennootschappelijke medezeggenschapsrecht op basis van de structuurregeling in Nederland nog het beoogde effect heeft. ${ }^{2}$ Wij sluiten dit artikel af met enkele conclusies (par. 7).

\section{De structuurregeling vanuit historisch perspectief}

Medezeggenschap betreft tegenwoordig een fundamenteel democratisch recht waarmee werknemers in staat worden gesteld om invloed uit te oefenen op

1 Zo bedroeg in 1973 het gemiddelde aantal uitgebrachte stemmen 54\%. De laatste jaren ligt dit percentage overigens veel hoger, in 2016 lag dit boven de 70\%. Zie R. Abma, D.P. van Kleef, N. Lemmers \& M. Olaerts, De algemene vergadering van Nederlandse beursvennootschappen, Deventer: Wolters Kluwer 2017, p. 7 en 10.

2 Wij gaan in dit artikel niet in op de toepassing van de structuurregeling bij de coöperatie en de onderlinge waarborgmaatschappij. 
beleidsbeslissingen die genomen worden in de onderneming of de instelling waarin zij werkzaam zijn. ${ }^{3}$ Dit recht is lang niet altijd vanzelfsprekend geweest. Dat is ook niet verwonderlijk; in een samenleving met gildes, eenmanszaken, en meester-gezelverhoudingen, nog voor de omwenteling van de industriële revolutie, was aan formele medezeggenschap nog geen behoefte. ${ }^{4}$ In het kielzog van deze historische omwenteling en de hiermee gepaard gaande opkomst van ondernemingsgewijze productie heeft het medezeggenschapsrecht zich ontwikkeld tot een opzichzelfstaand rechtsgebied in Nederland en in Europa. ${ }^{5}$ Zo dient een Nederlandse ondernemer die een onderneming in stand houdt waarin in de regel ten minste vijftig personen werkzaam zijn, op grond van art. 2 lid 1 Wet op de ondernemingsraden (WOR) een ondernemingsraad in te stellen. ${ }^{6}$ Een ondernemingsraad, bestaande uit een aantal werknemers van de betrokken onderneming, heeft op grond van deze wet bijzondere bevoegdheden. ${ }^{7}$ Deze ondernemingsraad kan daarmee daadwerkelijk invloed uitoefenen op het reilen en zeilen van de onderneming. ${ }^{8}$ Medezeggenschap betreft nu dan ook een essentieel onderdeel van de cultuur en de praktijk van het Nederlandse bedrijfsleven.

De focus binnen het Nederlandse medezeggenschapsrecht ligt op de zojuist genoemde WOR, maar medezeggenschap is ook breed vertakt in het Nederlandse

3 In de eerste plaats moet daarbij worden gewezen op het bepaalde in art. 19 lid $2 \mathrm{Gw}$, dat sinds 1983 de Nederlandse wetgever opdraagt regels op te stellen ten aanzien van de rechtspositie van werknemers en medezeggenschap. Zie ook H.F.J. Joosten, Medezeggenschap, in: C.W. de Monchy \& A.J. Woelders, Vademecum ondernemingsrecht, Deventer: Kluwer 1992, p. 18. Zie voorts de Richtlijn 2009/38/EG (PbEG 2001, L 294) met betrekking tot de Europese ondernemingsraad. Zie verder R. Blanpain, European works councils. The European Directive 2009/38/EC of 6 May 2009, Alphen aan den Rijn: Kluwer 2009, p. 1.

4 Asser/Maeijer \& Kroeze 2-I* 2015/607.

5 Rond het einde van de negentiende eeuw werden steeds vaker zogenoemde personeelskernen opgericht bij industriëlen. Pas na de Eerste Wereldoorlog (1914-1918) echter nam het belang van medezeggenschap pas echt snel toe. Zie J. van Drongelen \& S.F.H. Jellinghaus, Wet op de ondernemingsraden, Zutphen: Uitgeverij Paris 2008, p. 24.

6 Halverwege de vorige eeuw werd namelijk breed erkend dat werknemers inderdaad het recht hebben om hun stem te laten horen over verschillende aangelegenheden die de onderneming betreffen waarin zij werkzaam zijn. Met de WOR is beoogd een eerste wettelijke basis voor medezeggenschap binnen ondernemingen te creëren. Zie ook MvA bij het wetsvoorstel dat leidde tot de eerste Wet op de ondernemingsraden (Kamerstukken II 1948/49, 884, 5, p. 11). Zie verder J.J.M. van Mierlo, Medezeggenschap en de spanning tussen WOR en ondernemingsrecht (diss. Nijmegen), Deventer: Kluwer 2013, p. 9.

7 De WOR kent een breed ondernemingsbegrip, waardoor de toepassing van deze wet niet tot commerciële rechtspersonen is beperkt. Bevoegdheden van de ondernemingsraad op grond van de WOR zijn o.a. het geven van advies ten opzichte van bepaalde voorgenomen besluiten genoemd in art. 25 WOR en het instemmingsrecht voor de in art. 27 WOR genoemde voorgenomen besluiten. Zie Asser/Maeijer \& Kroeze 2-I* 2015/610 en 631.

8 Dat in de praktijk deze invloed daadwerkelijk voelbaar is, kan worden opgemaakt uit de vele zaken die een ondernemingsraad heeft ingesteld tegen het bedrijf waaronder hij ressorteert. Enkele voorbeelden hiervan zijn: HR 20 december 2002, NJ 2003/141 (Holland Casino), Hof Amsterdam (OK) 13 maart 2003, JOR 2003/6 (Corus) en Hof Amsterdam (OK) 5 augustus 2011, TRA 2012/8 (Printronix Nederland). 
privaatrecht. ${ }^{9}$ Reeds in 1971 kwam, op advies van de Commissie tot herziening van het ondernemingsrecht (genoemd naar haar voorzitter professor P.J. Verdam: de commissie-Verdam) en de SER, de zogeheten structuurregeling tot stand. ${ }^{10}$ Daarmee kent het vennootschapsrecht uit Boek 2 Burgerlijk Wetboek (BW) medezeggenschapsrechten toe aan ondernemingsraden. ${ }^{11}$ Centraal stond (en staat) in de Nederlandse regeling dat anders dan bij 'gewone' vennootschappen, het bestuur van een structuurvennootschap wordt benoemd en ontslagen door de raad van commissarissen (hierna: rvc). De bepalingen uit de Nederlandse structuurregeling voorzien voorts onder andere in een aanbevelingsrecht voor de ondernemingsraad met betrekking tot nieuwe leden van de rvc). Voor een derde van de te vervullen plaatsen geldt een versterkt aanbevelingsrecht. ${ }^{12}$

Het ontstaan van de structuurregeling is grotendeels op dezelfde wijze te duiden als het ontstaan van concernverhoudingen. Het steeds groter worden van ondernemingen heeft als resultaat gehad dat men anders is gaan denken over bestuur en toezicht binnen de onderneming. In het verlengde hiervan kwamen institutionele debatten over sociaaleconomische ordening, arbeiderszelfbestuur en 'social democracy' steeds meer in de brede maatschappelijke schijnwerpers. ${ }^{13}$ Sloot het bestaande juridische kader nog wel aan op de economische en maatschappelijke realiteit? En kon de algemene vergadering binnen groter wordende ondernemingen nog wel voldoende tegenwicht bieden aan het bestuur? ${ }^{14}$ Vanuit het bovenstaande kader bezien leidden maatschappelijke ontwikkelingen in de jaren zestig en zeventig van de vorige eeuw dan ook tot de invoering van de structuurregeling, waarbij in het bijzonder rekenschap is gegeven aan de sterke behoefte aan democratisering en medezeggenschap binnen het ondernemingsrecht. ${ }^{15}$ Op het eerste gezicht lijkt de structuurregeling dan ook naadloos aan te sluiten op de Nederlandse gedachte over het belang van medezeggenschap. Die gedachte, dat de onderneming niet alleen het verlengstuk of eigendom is van de aandeelhouders, maar juist een samenspel van diverse stakeholders, zoals het bestuur, kapitaalver-

9 L.C.J. Sprengers, De ondernemingsraad en de raad van commissarissen: een vorm van vennootschapsrechtelijke medezeggenschap, TAP 2017, afl. 2, par. 7.

10 Rapport 'Herziening van het ondernemingsrecht', op 26 november 1964 uitgebracht door de Commissie Ondernemingsrecht. Zie voorts het SER-advies 69/14 inzake de herziening van het ondernemingsrecht (advies van 19 september 1969). Deze herziening van het ondernemingsrecht heeft in 1971 geleid tot de zogenoemde Structuurwet: Wet van 6 mei 1971, Stb. 1971, 289. De Structuurwet is bij de invoering van Boek 2 BW daarin geïncorporeerd. Zie ook D. Dirks, B. van Hussen \& E. Soerjatin, Tekst en toelichting. Nieuwe structuurregeling, Den Haag: Sdu Uitgevers 2004, p. 15.

11 Zie ook M. Meyer, Employee participation in multinational corporations: Corporate governance and the role of works councils, TvOB 2017, afl. 4, p. 134-135 en R.H. van het Kaar, Medezeggenschap en internationale holdings, Ondernemingsrecht 2009/33.

12 Art. 2:158 lid 6 en 2:268 lid 6 BW.

13 M.J.G.C. Raaijmakers, De 'institutionele opvatting': grondslag en inhoud?, Ondernemingsrecht 2015/28, par. 3.3 .

14 S.M. Bartman, A.F.M. Dorresteijn \& M. Olaerts, Van het concern, Deventer: Wolters Kluwer 2016, p. 97.

15 W.W. de Nijs Bik, De structuurvennootschap. Bestuur, toezicht en corporate governance (R\&P nr. ONR6), Deventer: Kluwer 2013, par. 1.2. 
schaffers, afnemers, crediteuren, en in het bijzonder de werknemers, lag dan ook aan de invoering van de structuurregeling mede ten grondslag. ${ }^{16}$ Door de structuurregeling was bij grote vennootschappen sprake van een verschuiving van het zwaartepunt van de zeggenschap van de algemene vergadering naar de rvc.

In 2004 is de structuurregeling gewijzigd. ${ }^{17}$ De wetgever heeft hiermee evenwel geen gehoor gegeven aan degenen die hebben gepleit voor een algehele afschaffing van de structuurregeling. ${ }^{18}$ De herziening stond mede in het teken van een internationale discussie op het gebied van corporate governance en de versterking van de positie van de aandeelhouder. ${ }^{19}$ In het bijzonder door de opkomst van institutionele beleggers, waardoor het aandelenbezit weer wat meer geconcentreerd is geraakt, was de roep om meer bevoegdheden en mogelijkheden voor de aandeelhouder om het ondernemingsbestuur en het toezicht daarop ter verantwoording te kunnen roepen, versterkt. ${ }^{20}$ In de literatuur wordt ook wel gesteld dat de nieuwe structuurregeling een hernieuwde afweging is van verscheidene deelbelangen. Er is een nieuwe balans gezocht tussen de factoren kapitaal en arbeid binnen de onderneming, met ditmaal als zwaartepunt de kapitaalverschaffer. ${ }^{21} \mathrm{Bij}$ de invoering van de Structuurwet in 1971 lag het zwaartepunt nu juist bij de gelijkheid van de factoren arbeid en kapitaal. ${ }^{22}$ Is hiermee dan de keuze gevallen op het shareholdersmodel, ten gunste van het stakeholdersmodel? De wetgever meende in ieder geval van niet. ${ }^{23} \mathrm{Wel}$ is duidelijk dat deze herziening een vergroting van de invloed van aandeelhouders betrof. De macht binnen de onderneming is weer bij de aandeelhouder neergelegd: de algemene vergadering heeft nu het laatste woord over de benoeming en het ontslag van de rvc. Zij kan tevens,

16 W.W. de Nijs Bik, De nieuwe structuurregeling, Deventer: Kluwer 2004, p. 1. Werknemers worden in Nederland doorgaans gezien als behorend tot de belangrijkste stakeholders binnen een onderneming. Zie voor de stakeholdersgedachte in het Nederlandse (vennootschaps)recht o.a. I. Zaal, De reikwijdte van medezeggenschap (Mon. sociaal recht), Deventer: Kluwer 2014, par. 2.2.1 en L. Timmerman, Grondslagen van geldend ondernemingsrecht, Ondernemingsrecht 2009/2. Deze stakeholdersbenadering wordt gezien als de tegenhanger van de veelal in Angelsaksische landen heersende shareholdersbenadering.

17 De Wet wijziging structuurregeling werd op 9 juli 2004 aangenomen en werd op 1 oktober 2004 van kracht.

18 Congres 'Moet het wetsvoorstel aanpassing structuurregeling worden doorgezet?', Den Haag, 2 juli 2003, met bijdragen van minister Donner, L. Timmerman, P.F. van der Heijden, J.W. Winter, G. van Solinge en P. van Schilfgaarde, in: De Nijs Bik 2004, p. v; zie ook J.W.A. Biemans \& S-J. Spanjaard, Verslag van het Ondernemingsrecht-congres 'Moet het wetsvoorstel aanpassing structuurregeling worden doorgezet?', Ondernemingsrecht 2003/11, i.h.b. par. 7. Zeer stellig is F.J.P. van den Ingh, Requiem voor de structuurregeling. Het verdriet van Den Haag, Ondernemingsrecht 2001/8, p. 226 e.v.

19 Asser/Maeijer, Van Solinge \& Nieuwe Weme 2-II* 2009/519.

20 De discussie aan het einde van de twintigste eeuw wordt goed weergegeven in: F. Koning, Corporate governance en het recht van bezwaar in de structuurregeling, De NV 1997, afl. 1, par. II e.v.

21 De Nijs Bik 2004, p. vii. Zie voor een overzicht van de wijzigingen per 1 oktober 2004 Asser/ Maeijer, Van Solinge \& Nieuwe Weme 2-II* 2009/522.

22 Zie Zaal 2014, par. 2.6.2.1.

23 Kamerstukken II 2001/02, 28179, 5. 
met een gewone meerderheid van stemmen, ten minste een derde van het geplaatste kapitaal vertegenwoordigend, de voltallige rvc naar huis sturen. ${ }^{24}$

\section{De structuurregeling vanuit juridisch en rechtsvergelijkend perspectief}

\subsection{De toepassingscriteria en het begrip 'afhankelijke maatschappij' verduidelijkt}

De structuurregeling wordt van rechtswege op een vennootschap ${ }^{25}$ van toepassing indien zij gedurende drie onafgebroken jaren als in beginsel structuurplichtig bij het handelsregister staat ingeschreven. ${ }^{26}$ Indien een vrijstelling geldt, vindt deze regel evenwel geen toepassing. De hierboven genoemde inschrijving dient plaats te vinden zodra de vennootschap voldoet aan de navolgende (cumulatieve) criteria, ${ }^{27}$ namelijk indien

1 het geplaatste kapitaal van de vennootschap tezamen met de reserves volgens de balans met toelichting ten minste een bij koninklijk besluit vastgesteld grensbedrag beloopt; ${ }^{28}$

2 de vennootschap of een afhankelijke maatschappij krachtens wettelijke verplichting (op basis van de WOR) een ondernemingsraad heeft ingesteld; ${ }^{29}$ en

3 bij de vennootschap en haar afhankelijke maatschappijen ${ }^{30}$ tezamen in de regel ten minste honderd werknemers in Nederland werkzaam zijn.

Een rechtspersoon die een afhankelijke maatschappij is van een structuurvennootschap is vrijgesteld van het doen van opgaaf: hij hoeft de structuurregeling niet toe te passen. ${ }^{31}$ Vanuit het perspectief van de factor arbeid bewerkstelligt het begrip afhankelijke maatschappij in de structuurregeling dat werknemers van een concern in Nederland toegerekend worden (men spreekt ook wel van samentelling) aan de bovenliggende structuurvennootschap. Als gevolg hiervan kan de centrale ondernemingsraad invloed uitoefenen op de samenstelling van de rvc van de moederonderneming door gebruik te maken van zijn (versterkte) recht van aan-

24 Dirks, Van Hussen \& Soerjatin 2004, p. 26-27.

25 Wij gaan niet in op de structuurregeling bij vennootschappen met een monistisch bestuursmodel. Zie hierover o.a. Asser/Maeijer, Van Solinge \& Nieuwe Weme 2-II* 2009/558; De Nijs Bik 2013, par. 4.

26 Art. 2:153/263 lid 1-3 BW. De vennootschap moet haar statuten aanpassen, uiterlijk op de dag dat het voor haar geldende structuurregime op haar van toepassing wordt. Zie art. 2:154/264 lid 3 BW.

27 Art. 2:153/263 lid 2 BW, Stb. 2015, 349; De Nijs Bik 2013, par. 2.2; Bartman, Dorresteijn \& Olaerts 2016, p. 104.

28 Het geplaatste kapitaal van de vennootschap tezamen met de reserves volgens de balans met toelichting bedraagt ten minste $€ 16$ miljoen. De laatste wijziging bij AMvB vond plaats op 1 oktober 2004 (Kamerstukken II 2001/02, 28179, 1-2, p. 12). Bij de invoering van de structuurregeling in 1971 was dit grensbedrag $f 10$ miljoen.

29 Art. 2 lid 1 en 5a lid 1 WOR. Aan deze eis is nadrukkelijk niet voldaan indien bij cao of vrijwillig een ondernemingsraad is ingesteld. Zie Asser/Maeijer, Van Solinge \& Nieuwe Weme 2-II* 2009/527.

30 In art. 2:152 en 2:262 BW is het begrip afhankelijke maatschappij gedefinieerd.

31 Art. 2:152/265 BW; GS Rechtspersonen, art. 2:152 BW, aant. 2.1; Asser/Maeijer, Van Solinge \& Nieuwe Weme 2-II* 2009/523. 
beveling. ${ }^{32}$ Dat komt doordat de gedachte is dat alleen de moedermaatschappij binnen het concern een structuurvennootschap is. Hierna zal blijken dat deze gedachte achter de structuurregeling aan erosie onderhevig is.

\subsection{Vrijwillige toepassing}

Iedere vennootschap die niet voldoet aan de eisen van de (al dan niet verzwakte vorm van de) structuurregeling kan kiezen voor een vrijwillige toepassing van de structuurregeling door haar statuten zodanig in te richten. Er dient wel een ondernemingsraad te zijn ingesteld waar de bepalingen van de WOR op van toepassing zijn. ${ }^{33}$ Vrijwillige toepassing van het structuurregime leidt tot toepasselijkheid van bepaalde elementen uit de regeling. Daarbij moet de vennootschap bedacht zijn op de bevoegdheden van haar ondernemingsraad; het toepassen of intrekken van het vrijwillig toegepaste structuurregime betreft namelijk een adviesplichtig besluit in de zin van art. 25 WOR. ${ }^{34}$ Voorts dient de algemene vergadering een expliciet besluit te nemen over de toepassing of intrekking van de vrijwillige toepassing van het structuurregime. ${ }^{35}$ Het vrijwillige (verzwakte) structuurregime wordt in de praktijk vaak toegepast binnen concernverhoudingen. Hierdoor wordt beoogd een vrijstelling te bereiken voor een van die vennootschap afhankelijke maatschappij. ${ }^{36}$

\subsection{Vrijstellingen en het verzwakte regime}

Al bij de invoering van de structuurregeling was de wetgever bedacht op mogelijke complicaties bij toepassing van de Nederlandse structuurregeling in (internationaal) concernverband. ${ }^{37}$ Volledige toepassing van de structuurregeling op andere groepsmaatschappijen valt in beginsel niet te rijmen met de gedachte dat binnen een concern het beleid aan de top wordt vastgesteld. ${ }^{38}$ Het principe van de structuurregeling is dan ook dat alleen op de 'bovenste' vennootschap het structuurregime van toepassing is. ${ }^{39}$ De wetgever heeft het bovenstaande vormgegeven door de volledige vrijstellingen van art. 2:153/263 lid 3 BW enerzijds, en door het zogenoemde 'verzwakte' regime van art. 2:155/265 BW anderzijds.

Een volledige vrijstelling met betrekking tot het doen van opgaaf bij het handelsregister, inhoudende dat de vennootschap voldoet aan de eisen van de structuurregeling, geldt voor: 2014, par. 4.5.1; Kamerstukken II 2001/02, 28179, 3, p. 3. Art. 2:157/267 BW (jo. art. 2:154/263 lid 4-7 BW).

34 HR 26 januari 1994, NJ 1994/545 (Heuga Holding); Hof Amsterdam (OK) 1 juli 2016, RO 2016/57 (OR/Thomas Cook Nederland).

35 Art. 2:154/264 lid 4 BW; R. Abma e.a., De algemene vergadering van Nederlandse beursvennootschappen (R\&P nr. ONR9), Deventer: Wolters Kluwer 2017, p. 78.

36 Asser/Maeijer, Van Solinge \& Nieuwe Weme 2-II* 2009/534 en 545.

37 Asser/Maeijer, Van Solinge \& Nieuwe Weme 2-II* 2009/542; SER-advies 69/14.

38 J. Winter, J.B. Wezeman \& J. Schoonbrood, Van Schilfgaarde. Van de BV en de NV, Deventer: Wolters Kluwer 2017, nrs. 12 en 146.

39 MvT Structuurwet, p. 14, linkerkolom; Maeijer, Wetsgeschiedenis, p. IXf - art. III-3, in: GS Rechtspersonen, art. 2:153 lid 3 sub a BW, aant. 5.1. 
1 een afhankelijke maatschappij van een structuurvennootschap (de dochtervrijstelling) ${ }^{40}$

2 een vennootschap wier werkzaamheid zich uitsluitend of nagenoeg uitsluitend beperkt tot het beheer en de financiering van groepsmaatschappijen, en van haar en hun deelnemingen in andere rechtspersonen, mits de werknemers in dienst van de vennootschap en de groepsmaatschappijen in meerderheid buiten Nederland werkzaam zijn (de internationale holdingvennootschap) ${ }^{41}$

3 een vennootschap die aan een dergelijk onder 2 genoemd concern uitsluitend of nagenoeg uitsluitend diensten verleent ten behoeve van het beheer en de financiering; ${ }^{42}$ of

4 een joint-venturevennootschap waarin twee of meer structuurvennootschappen voor ten minste $50 \%$ van het geplaatste kapitaal deelnemen (de joint-venturevrijstelling). ${ }^{43}$

Daarbij is het van belang om op te merken dat bij deze vrijstellingen reeds voldoende is dat er sprake is van afhankelijkheid van een vennootschap waarop het verzwakte structuurregime van toepassing is. Er hoeft dus geen sprake te zijn van een aan het volledige structuurregime onderworpen vennootschap binnen het concern. ${ }^{44}$ Ook van belang is de internationale holdingvrijstelling; veel in Nederland gevestigde concerns vallen hieronder.

De wetgever heeft, teneinde het vestigingsklimaat in Nederland niet te verslechteren, ook voorzien in een verzwakte variant van de structuurregeling. ${ }^{45}$ Onder meer geldt het verzwakte regime voor een vennootschap waarin een deelneming voor ten minste de helft van het geplaatste kapitaal wordt gehouden door: ${ }^{46}$

40 Art. 2:153/263 lid 3 sub a BW (jo. art. 2:152/262 BW).

41 Art. 2:153/263 lid 3 sub b BW. Het gaat hier om de hoeveelheid werknemers die niet in Nederland werkzaam zijn. Dit moet in ieder geval de meerderheid betreffen. Zie Bartman, Dorresteijn \& Olaerts 2016, p. 110.

42 Art. 2:153/263 lid 3 sub c BW.

43 Art. 2:153/263 lid 3 sub d BW. Zie ook Bartman, Dorresteijn \& Olaerts 2016, p. 110-111.

44 Asser/Maeijer, Van Solinge \& Nieuwe Weme 2-II* 2009/545-546; GS Rechtspersonen, art. 2:155a/265a BW, aant. 3.

45 Zie Bartman, Dorresteijn \& Olaerts 2016, p. 112.

46 Zie Asser/Maeijer, Van Solinge \& Nieuwe Weme 2-II* 2009/544. Van belang is ook de vaststelling dat de vennootschap in beginsel verplicht is tot het doen van opgaaf: zij is een structuurvennootschap (Van Schilfgaarde/Winter, Wezeman \& Schoonbrood 2017/147). Voorts kan worden gewezen op de mogelijkheid van het verzwakte regime voor besloten verhoudingen in art. 2:155a/ 265a BW. Zie daarover Bartman, Dorresteijn \& Olaerts 2016, p. 116. 
1 een rechtspersoon waarvan de werknemers in meerderheid buiten Nederland werkzaam zijn (een internationale rechtspersoon), ${ }^{47}$ of door afhankelijke maatschappijen daarvan;

2 een joint venture van een aantal van de onder 1 genoemde rechtspersonen (samenwerkende internationale rechtspersonen), ${ }^{48}$ of afhankelijke maatschappijen daarvan; of

3 een joint venture van een of meer internationale rechtspersonen met een of meer structuurrechtspersonen, dan wel afhankelijke maatschappijen daarvan. ${ }^{49}$

Het verzwakte regime is geformuleerd als een vrijstelling van de structuurregeling. Het is echter slechts een beperkte vrijstelling, want sinds de inwerkingtreding van de herziene structuurregeling in 2004 verschilt het verzwakte structuurregime nog slechts op één punt van het volledige structuurregime. Dat punt betreft de bevoegdheid tot benoeming en ontslag van de bestuurders van de structuurvennootschap. ${ }^{50}$ Deze bevoegdheid blijft in geval van het verzwakte structuurregime berusten bij de aandeelhouders. Dat betekent ook dat de moedermaatschappij binnen een concern zelf de bestuurders van een onder art. 2:155/265 BW vallende dochtermaatschappij kan ontslaan. De overige bepalingen van de structuurregeling blijven onverkort van toepassing. ${ }^{51}$ Van belang is dat op basis van art. 2:155/265 lid 2 en 3 BW het verzwakte regime evenwel niet van toepassing is indien de werknemers in dienst van de vennootschap, tezamen met die in dienst van de internationale rechtspersoon of rechtspersonen, in meerderheid in Nederland werkzaam zijn. Bij deze vaststelling worden onder werknemers, in dienst van een internationale rechtspersoon, begrepen de werknemers in dienst van groepsmaatschappijen daarvan. ${ }^{52}$

47 Art. 2:155/265 lid 1 sub a BW. Zie Bartman, Dorresteijn \& Olaerts 2016, p. 113. Aan deze kwalificatie kunnen zowel Nederlandse als buitenlandse rechtspersonen voldoen. Het gaat er steeds om of de werknemers van de rechtspersoon in meerderheid buiten Nederland werkzaam zijn. Daaronder worden ingevolge lid 3 ook begrepen de werknemers in dienst van de groepsmaatschappijen binnen het concern. Een voor de hand liggende constructie is dus een vrijgestelde internationale holding met daaronder een Nederlandse subholding of werkmaatschappij waarop het verzwakte regime van toepassing is. Zie Asser/Maeijer, Van Solinge \& Nieuwe Weme 2-II* 2009/550.

48 Art. 2:155/265 lid 1 sub b BW.

49 Art. 2:155/265 lid 1 sub c BW.

50 Dat betekent dat art. 2:162/272 BW niet geldt. Zie Asser/Maeijer, Van Solinge \& Nieuwe Weme 2-II* 2009/549; Van Schilfgaarde/Winter, Wezeman \& Schoonbrood 2017/147. Het verzwakte regime staat ook wel bekend als het verlichte, gemitigeerde of gematigde structuurregime. Deze termen zijn onderling uitwisselbaar.

51 Behoudens eventuele statutaire afwijkingen. Zie Asser/Maeijer, Van Solinge \& Nieuwe Weme 2-II* 2009/549.

52 Zie Bartman, Dorresteijn \& Olaerts 2016, par. IV.7.1. 


\subsection{Inhoud van de structuurregeling: samenstelling en benoeming rvc}

Het minimumaantal leden voor de rvc van een structuurvennootschap bedraagt drie. Voor de te vervullen plaatsen stelt de rvc zelf een profielschets op. ${ }^{53}$ Hier worden de ondernemingsraad en de algemene vergadering bij betrokken. In concernverband is de centrale ondernemingsraad daar meestal toe bevoegd, op grond van art. 35 WOR. ${ }^{54}$ De hoofdregel is vervolgens dat de algemene vergadering de commissarissen, op voordracht van de rvc, benoemt. De algemene vergadering heeft met betrekking tot de rvc het laatste woord over zowel benoeming als ontslag. ${ }^{55}$ De reden voor de verplichtstelling van de profielschets en voordracht is het benadrukken van de onafhankelijke positie van de rvc; hij moet zich 'zonder last of ruggespraak' kunnen richten op het belang van de vennootschap en de met haar verbonden onderneming. ${ }^{56}$ De wet schrijft voorts nog een aantal beperkingen voor met betrekking tot commissarissen: rechtspersonen, werknemers van de rechtspersoon (of van afhankelijke maatschappijen) en bepaalde vakbondsfunctionarissen mogen geen commissaris worden. ${ }^{57}$ In concernverhoudingen is voorts relevant dat de rvc in voldoende mate onafhankelijk moet zijn van de moedervennootschap. ${ }^{58}$

Zowel de ondernemingsraad als de algemene vergadering heeft het recht om personen aan te bevelen. ${ }^{59}$ De ondernemingsraad heeft daarnaast, voor een derde van het aantal leden van de rvc, een versterkt (niet-bindend) aanbevelingsrecht. De aanbeveling wordt overgenomen, tenzij de rvc tegen de kandidaat bezwaar maakt. Dat kan hij doen op twee gronden, te weten: (1) de verwachting dat de aanbevolen kandidaat ongeschikt zal zijn voor de vervulling van zijn taak, of (2) de verwachting dat de rvc bij benoeming van die persoon niet naar behoren zal

53 Deze wordt bij iedere wijziging besproken met de algemene vergadering en de ondernemingsraad. Daarnaast bevat ook de Nederlandse Corporate Governance Code een aantal bepalingen met betrekking tot de profielschets.

54 Zie Asser/Maeijer, Van Solinge \& Nieuwe Weme 2-II* 2009/560.

55 Zie Asser/Maeijer, Van Solinge \& Nieuwe Weme 2-II* 2009/568-572 en 580-591.

56 Kamerstukken II 2001/02, 28179, 3, p. 32-34. Zie Asser/Maeijer, Van Solinge \& Nieuwe Weme 2-II* 2009/560. Dat geldt ook voor de via het versterkte aanbevelingsrecht benoemde commissarissen (Kamerstukken II 2001/02, 28179, 5, p. 43).

57 Art. 2:140/250 en 2:160/270 BW; GS Rechtspersonen, art. 2:142 BW, aant. 7. Zie Bartman, Dorresteijn \& Olaerts 2016, p. 119-120.

58 Zie Hof Amsterdam (OK) 2 februari 1989, NJ 1990/86 (Kodak). Het gaat dan om de samenstelling van de rvc als geheel. Zie voorts de Corus-zaak als een goed voorbeeld van deze balans: accommoderen van een internationaal concern in de (verzwakte) structuurregeling en het mogelijk maken van evenwichtig toezicht binnen de onderscheiden vennootschappen van het concern. Zie Hof Amsterdam (OK) 13 maart 2003, NJ 2003/248 (Corus), i.h.b. r.o. 3.4.

59 Art. 2:158/268 lid 5 BW. Zie Asser/Maeijer, Van Solinge \& Nieuwe Weme 2-II* 2009/562. 
zijn samengesteld. ${ }^{60}$ Bezwaar verplicht de rvc tot overleg met de ondernemingsraad. Leidt dat tot niets, dan kan de Ondernemingskamer (OK) het bezwaar eventueel gegrond verklaren. ${ }^{61}$ Een overgenomen aanbeveling op grond van het normale aanbevelingsrecht telt niet mee voor de uitoefening van het versterkte aanbevelingsrecht. Overigens kan in de statuten worden afgeweken van diverse onderdelen van de regeling met betrekking tot aanbeveling, bezwaar en benoeming van commissarissen. Hiervoor zijn goedkeuring van de rvc en instemming van de ondernemingsraad vereist. ${ }^{62}$ Op deze manier is het bijvoorbeeld mogelijk om toch weer een systeem van gecontroleerde coöptatie in te voeren. ${ }^{63}$ Mogelijk worden elementen uit de structuurregeling dus ook gebruikt als bargaining chip tijdens interne onderhandelingen.

\subsection{Inhoud van de structuurregeling: bevoegdheden rvc}

De rvc houdt toezicht op het beleid van het bestuur en op de algemene gang van zaken in de rechtspersoon en de met hem verbonden onderneming. Indien hij op topholdingniveau is ingesteld, strekt het toezicht zich tevens uit tot het concernbeleid. ${ }^{64}$ De structuurregeling kent twee bijzondere bevoegdheden toe aan de rvc, te weten: (1) benoeming, schorsing en ontslag van bestuurders en (2) goedkeuring van belangrijke bestuursbesluiten. ${ }^{65}$ De bevoegdheid tot benoemen van bestuurders kan niet worden beperkt door een bindende voordracht. Wel dient de rvc de algemene vergadering (of, indien ingesteld, de aandeelhouderscommissie)

60 Art. 2:158/268 lid 6 BW. Zie Asser/Maeijer, Van Solinge \& Nieuwe Weme 2-II* 2009/563. De bezwaargronden zien voornamelijk op het feit dat er bijvoorbeeld essentiële deskundigheid of ervaring ontbreekt, dan wel op het bestaan van sterke onenigheid bij de benoeming. Deze gronden worden verder ingevuld in de jurisprudentie: Hof Amsterdam (OK) 2 februari 1989, NJ 1990/86 (Kodak); Hof Amsterdam (OK) 24 september 1992, NJ 1993/39 (Nedlloyd); Hof Amsterdam (OK) 11 april 1991, NJ 1991/533 (REGEV). Daarnaast moet worden gewezen op het feit dat de algemene vergadering niet gebonden is aan de voordracht van de rvc (art. 2:158/268 lid 9 BW). Wel kan een eventuele afwijzing door de algemene vergadering worden getoetst aan de redelijkheid en billijkheid van art. 2:8 BW.

61 Wordt het verzoek gehonoreerd, dan kan de ondernemingsraad opnieuw een aanbeveling doen. Tegen de beschikking van de OK staat geen hoger beroep of cassatie open. Zie Bartman, Dorresteijn \& Olaerts 2016, p. 117.

62 Art. 2:158/268 lid 12 BW. Zie Asser/Maeijer, Van Solinge \& Nieuwe Weme 2-II* 2009/577; Bartman, Dorresteijn \& Olaerts 2016, p. 118. De gedachte achter deze mogelijkheid betrof het willen voorzien in de behoefte aan maatwerk en flexibilisering: Kamerstukken II 2000/01, 25732, 17 , p. 63; Kamerstukken II 2001/02, 28179, 3, p. 37. Zie voor een bespreking in de literatuur: G.N.H. Kemperink, P.A.M. Witteveen \& H. Reumkens, Het ondergeschoven kind van de structuurregeling, Ondernemingsrecht 2006/29.

63 Dit was de wijze waarop de structuurregeling voor 2004 vormgegeven was. Zie ook Rb. Amsterdam 26 maart 2008, JOR 2008/125 (Delta Lloyd/Aviva) en Asser/Maeijer, Van Solinge \& Nieuwe Weme 2-II* 2009/561 en 577.

64 HR 10 januari 1990, NJ 1990/465, m.nt. Maeijer (Ogem), r.o. 9.2. Zie Bartman, Dorresteijn \& Olaerts 2016, p. 122.

65 Art. 2:162/272 en 2:164/274 BW. 
op de hoogte te stellen van de aanstaande benoeming, op straffe van vernietigbaarheid van de benoeming. ${ }^{66}$

Bezien vanuit deze bevoegdheden die een rvc toebedeeld krijgt wanneer hij onder toepassing van de structuurregeling is ingesteld, wordt duidelijk waarom het voor een ondernemingsraad van belang is dat hij invloed uit kan oefenen op de samenstelling van dit orgaan. Wanneer de hoogstgeplaatste ondernemingsraad binnen een concern evenwel slechts de samenstelling van de rvc van een onderliggende groepsmaatschappij kan beïnvloeden, heeft dit verstrekkende consequenties voor de effectiviteit van het vennootschappelijke medezeggenschapsrecht uit de structuurregeling. Binnen (internationale) concernverhoudingen fungeren groepsmaatschappijen nogal eens slechts als een doorgeefluik van de op topholdingniveau vastgestelde strategie. ${ }^{67}$

\subsection{De Duitse regeling}

Kort verdient de Duitse regeling voor vennootschappelijke medezeggenschap enige aandacht. Bij toepassing van het Duitse Mitbestimmungsgesetz (MitbestG) dient dwingendrechtelijk de helft van de Aufsichtsrat uit werknemersvertegenwoordigers te bestaan. ${ }^{68}$ Deze worden, afhankelijk van het aantal werknemers, direct of indirect gekozen door Duitse werknemers. ${ }^{69}$ Het aantal commissarissen is afhankelijk van het aantal werknemers dat in dienst is bij het concern in Duitsland. ${ }^{70}$ Er bestaat geen 'verzwakte' variant of vrijstelling voor bijvoorbeeld internationale holdings. Het Mitbestimmungsrecht is echter niet zonder controverse. Het kiesrecht op grond van het MitbestG (\$7) komt enkel toe aan werknemers van in Duitsland gevestigde (concern)vennootschappen en filialen daarvan. Werknemers buiten Duitsland vallen dus buiten de boot. Het bekende Duitse concern TUI bijvoorbeeld, een onderneming die zich richt op het verzorgen van vakanties, heeft wereldwijd ruim 70.000 werknemers in dienst. Hiervan zijn er ongeveer 10.000 in Duitsland werkzaam. Is er sprake van indirecte discriminatie naar nati-

66 Er is in een dergelijk geval strijd met een wettelijke bepaling die de totstandkoming van besluiten regelt (art. 2:15 lid 1 sub a BW). Zie Asser/Maeijer, Van Solinge \& Nieuwe Weme 2-II* 2009/596; De Nijs Bik 2013, par. 5.3.

67 W. Bosse, Functioneert de subholding als schild tegen de invloed van Nederlandse werknemers?, TVVS 1984, afl. 8, p. 193.

68 Betoogd wordt wel dat, hoewel de helft van de Aufsichtsrat uit werknemersvertegenwoordigers bestaat, er in feite vaak sprake is van Quasi-Parität binnen de Aufsichtsrat. Dit vanwege de dubbele stem van de voorzitter, die in de praktijk altijd een vertegenwoordiger is van de aandeelhouders. Vermelding verdient overigens dat het gebruik van deze doorslaggevende stem zeldzaam is. Zie M. Roth, Corporate boards in Germany, in: P. Davies e.a. (red.), Corporate boards in law and practice: A comparative analysis in Europe, Oxford: Oxford University Press 2013, p. 334. Zie ook T. Keijzer \& M. van Ginneken, Het Mitbestimmungsrecht op de schop?, AA 2017, afl. 1, p. 26-40.

69 Er vinden directe verkiezingen plaats indien er minder dan 8000 werknemers in dienst zijn van het concern $(\$ 9(2)$ Mitbest $G)$. In de overige gevallen vinden er indirecte verkiezingen plaats (§9(1), 10 MitbestG).

70 Is dat aantal onder de 10.000, dan dienen er 12 commissarissen te zijn. Tussen 10.000 en 20.000 werknemers zijn er 16 commissarissen. Daarboven dient de vennootschap een Aufsichtsrat in te stellen met 20 leden (§7(1) MitbestG). 
onaliteit (art. 18 Verdrag betreffende de werking van de Europese Unie (VWEU)) wanneer de meerderheid van de werknemers van het concern TUI in het buitenland werkzaam is en zij zich niet verkiesbaar mogen stellen en niet mogen meebeslissen over de samenstelling van de Aufsichtsrat (en dus de koers van het concern) ${ }^{71}$ De Duitse kwestie inzake TUI is inmiddels (marginaal) door het Hof van Justitie van de Europese Unie beoordeeld. ${ }^{72}$ Het Hof oordeelt dat geen sprake is van een beperking van het Unierecht. Deze kwestie betreft evenwel een nog niet (volledig) geharmoniseerd onderwerp: vennootschappelijke medezeggenschap. Het is dan ook aan de nationale wetgever om de territoriale reikwijdte van deze vorm van medezeggenschap te bepalen. Wel is diezelfde territoriale reikwijdte een knelpunt. ${ }^{73}$ In het geval van TUI zijn het slechts de 10.000 werknemers in Duitsland die vennootschappelijke medezeggenschap kunnen uitoefenen. ${ }^{74}$ De overige 60.000 werknemers moeten het zonder enige vorm van inspraak aan de top van de onderneming waarvoor zij werkzaam zijn, stellen.

\subsection{Tussenevaluatie}

De Nederlandse structuurregeling voorziet in uitgebreide voorschriften over de toepassing, ontheffing, vrijstellingen en bevoegdheden voor de rvc. De grote verscheidenheid aan varianten van de structuurregeling kan echter tot onduidelijkheid leiden en zorgt er ook voor dat het voor internationale concerns mogelijk is om de structuurregeling op de voor hen gewenste wijze toe te passen. Dat wordt het duidelijkst ingeval een naar Nederlands recht opgerichte moedervennootschap aandelen houdt in een Nederlandse subholding waarop het verzwakte structuurregime van toepassing is. Deze subholding houdt op haar beurt alle aandelen in de Nederlandse werkmaatschappijen. Inherent aan de systematiek van de structuurregeling is dat, al naar gelang het bedrijfsleven steeds internationaler wordt, dit leidt tot uitholling van de mogelijkheid voor werknemers om invloed uit te oefenen aan de 'top van de onderneming'. Aan de andere kant van het spectrum staat het Duitse Mitbestimmungsrecht, dat dwingendrechtelijk bepaalt dat in Duitsland werkzame werknemers meebeslissen over de samenstelling van de Aufsichtsrat van de topholding. Werknemers nemen zelfs plaats in dit orgaan. Bij ons buurland lijkt de vennootschappelijke medezeggenschap dan ook effectiever in de praktijk te worden gebracht. Toch wringt de Duitse regeling ook, omdat de buitenlandse werknemers geen enkele invloed hebben. Net zoals de Duitse regeling, heeft ook de Nederlandse structuurregeling al lange tijd geen materiële wijziging meer ondergaan. Bedrijven zijn, in beide landen, echter wel steeds internationaler

71 Zie ook J.J. du Plessis \& O. Sandrock, The rise and fall of supervisory codetermination in Germany?, International Company and Commercial Law Review 2005, afl. 2.

72 Met betrekking tot TUI zijn in eerste instantie enkele procedures gevoerd bij Duitse lagere rechters. In het laatste oordeel van het Kammergericht Berlin was overwogen dat schending van het Unierecht mogelijk was, en dat discriminatie naar nationaliteit denkbaar werd geacht. Zie Kammergericht Berlin 16 oktober 2015, 14 W 89/15, AG 2015, p. 872. Zie ook Keijzer \& Van Ginneken 2017.

74 Illustratief zijn ook de observaties in de Erzberger-zaak door de Europese Commissie, pleitend voor uitbreiding van medezeggenschapsrechten voor alle Europese werknemers van een in Duitsland statutair gevestigd concern. Zie HvJ EU 18 juli 2017, C-566/15, JOR 2017/284, par. 2. 
geworden. De territoriale reikwijdte van het vennootschappelijk medezeggenschapsrecht lijkt daarmee haar aansluiting te hebben verloren met de economische werkelijkheid.

\section{De structuurregeling in de praktijk}

Voor de effectieve uitoefening van vennootschappelijke medezeggenschap is vereist dat de centrale ondernemingsraad binnen het concern beschikt over deze bevoegdheid op het niveau van de topholding. Om een beeld te schetsen van de toepassing van de structuurregeling bij grote ondernemingen van Nederlandse origine, of met veel activiteiten in Nederland, hebben wij de statuten onderzocht van de ondernemingen die genoteerd staan aan de AEX en van een aantal andere Nederlandse ondernemingen die zich als internationale onderneming manifesteren. ${ }^{75}$ Dit heeft geleid tot het volgende overzicht:

Tabel 1

\begin{tabular}{|c|c|c|}
\hline Onderneming $^{a}$ & Geldend regime $^{b}$ & Voordracht/aanbeveling rvc ${ }^{c}$ \\
\hline a.s.r. Nederland & volledig regime & $\mathrm{av}+\mathrm{rvc}+\mathrm{cor}$ (versterkt) \\
\hline Aalberts Industries & n.v.t. & houder van prioriteitsaandelen \\
\hline ABN AMRO Bank & volledig regime & av + cor (versterkt) \\
\hline Achmea & volledig regime & $\mathrm{av}+\mathrm{rvc}+\mathrm{cor}$ (versterkt) \\
\hline$A E G O N$ & n.v.t. & rvc \\
\hline Ahold Delhaize & n.v.t. & av \\
\hline Air France - KLM & niet mogelijk & av \\
\hline AkzoNobel & n.v.t. & av + houder van prioriteitsaandelen \\
\hline Altice & niet mogelijk & av + houder van prioriteitsaandelen \\
\hline ArcelorMittal & niet mogelijk & av \\
\hline ASML Holding & volledig regime & av + cor (versterkt) \\
\hline Boskalis & n.v.t. & $\mathrm{av}+\mathrm{rvc}$ \\
\hline DSM & n.v.t. & $\mathrm{av}+\mathrm{rvc}$ \\
\hline Fugro & n.v.t. & av \\
\hline Galapagos & n.v.t. & av \\
\hline Gemalto & n.v.t. & $a v+r v c$ \\
\hline Heineken & n.v.t. & aandeelhouderscommissie + rvc \\
\hline ING Bank & n.v.t. & $\mathrm{av}+\mathrm{rvc}$ \\
\hline Koninklijke BAM Groep & verzwakt regime & $\mathrm{av}+\operatorname{cor}($ versterkt) \\
\hline KPMG & volledig regime & $\mathrm{av}+\mathrm{rvc}+\mathrm{cor}$ (versterkt) \\
\hline KPN & volledig regime & $\mathrm{av}+\mathrm{rvc}+\mathrm{cor}$ (versterkt) \\
\hline NN Group & volledig regime & $\mathrm{av}+\mathrm{rvc}+\mathrm{cor}$ (versterkt) \\
\hline$N X P$ & n.v.t. & $\mathrm{av}+\mathrm{rvc}$ \\
\hline
\end{tabular}


Tabel 1 (Vervolg)

\begin{tabular}{lll}
\hline Onderneming $^{\mathbf{a}}$ & Geldend regime & (oordracht/aanbeveling rvc $^{\mathbf{c}}$ \\
\hline Philips & n.v.t. & av + rvc \\
Rabobank & bijzonder regime & ledenraad + bestuur + cor \\
Randstad & n.v.t. & av \\
RELX (Reed Elsevier) & niet mogelijk & av + rvc \\
Royal Dutch Shell & niet mogelijk & av \\
SBM Offshore & n.v.t. & av + rvc \\
TNT Express & n.v.t. & av + rvc \\
TomTom & n.v.t. & av + rvc \\
Unibail-Rodamco & n.v.t. & av \\
Unilever & niet mogelijk & bestuur + aandeelhouder(s) \\
Vopak & n.v.t. & av + rvc \\
Wolters Kluwer & n.v.t. & av + rvc \\
\hline
\end{tabular}

${ }^{a}$ De gegevens zijn afkomstig van de op het internet openbaar te raadplegen statuten van iedere onderneming. De ondernemingen zijn alle naamloze vennootschappen, met uitzondering van Air France - KLM (s.a.), Altice (s.a.), ArcelorMittal (s.a.), Achmea (B.V.), Unilever (plc.), Rabobank (coöperatie U.A.), Royal Dutch Shell (plc.), RELX (plc.) en Unibail-Rodamco (SE).

b Voor de vaststelling is gebruik gemaakt van het feit of de onderneming een (versterkt) aanbevelingsrecht verleent aan haar ondernemingsraad of uitdrukkelijk verwezen wordt naar de structuurregeling in haar statuten.

${ }^{\mathrm{c}}$ Het gaat hier om organen binnen de onderneming die kandidaten kunnen voordragen of aanbevelen voor een zetel in de rvc of voor een positie als niet-uitvoerende bestuurder. Deze kolom dient ter illustratie voor de positie van de factor arbeid aan de top van de onderneming, en vormt geen onderdeel van de vaststelling of er sprake is van toepassing van de structuurregeling.

Uit dit onderzoek blijkt dat 8 van de 35 ondernemingen het, al dan niet verzwakte, structuurregime op topholdingniveau toepassen. De bestudeerde statutaire regelingen geven aldus blijk van een zeer beperkte formele betrokkenheid van de ondernemingsraad bij de samenstelling van het toezichthoudende orgaan binnen de bestudeerde concerns. ${ }^{76}$ Dat wil zeggen: op topholdingniveau, want voor dit artikel zijn slechts de statuten geraadpleegd van de moedermaatschappij binnen het concern. Het is dus niet ondenkbaar dat ondernemingsraden van deze ondernemingen wel invloed hebben op de samenstelling van het toezicht op het bestuur van een onderliggende groepsmaatschappij. Desalniettemin betekent dat uitholling van de vennootschappelijke medezeggenschap. Het verdient overigens vermelding dat mogelijk in een convenant aanvullende bevoegdheden voor de ondernemingsraad zijn bedongen.

Hoe zit het dan met ondernemingen waar het versterkte recht van aanbeveling wel is verleend aan de ondernemingsraad? Het hebben van een (versterkt) aanbevelingsrecht betekent niet dat het recht ook daadwerkelijk wordt uitgeoefend. In 
de praktijk wordt namelijk niet altijd van het al dan niet versterkte recht van aanbeveling gebruik gemaakt, zo hebben wij vanuit de praktijk vernomen. ${ }^{77}$ Uit onderzoek uit 2016 blijkt dat bij ruim 30\% van 42 in Nederland gevestigde concerns geen gebruik wordt maakt van het (statutair vastgelegde) versterkte aanbevelingsrecht. Dat ligt meestal aan onwetendheid of aan de opvatting dat het gebruik maken van dit recht geen toegevoegde waarde heeft. ${ }^{78}$ Bij structuurvennootschappen in het algemeen bestaat deze problematiek al binnen ruim twee derde van de onderzochte ondernemingsraden. ${ }^{79}$ Ook bleek dat $16 \%$ van deze ondernemingen op geen enkel niveau binnen de organisatie een toezichthoudend orgaan conform de structuurregeling heeft ingesteld. ${ }^{80}$ Hier ligt dus ook een opdracht voor ondernemingsraden om het doen van aanbevelingen, wanneer zij daartoe gerechtigd zijn, serieus tot hun taak te rekenen. Daarbij is van belang dat zij niet alleen van het recht gebruik maken, maar tevens wordt toegezien op de kwaliteit van de voorgedragen kandidaat. ${ }^{81}$ Dat komt de effectiviteit van vennootschappelijke medezeggenschap ten goede. In een SER-advies uit 2001 werd deze problematiek als volgt beschreven:

'(...) dat in grote Nederlandse internationals het hoogste niveau inmiddels buiten bereik is geraakt van zowel de ondernemingsraad als de raad van commissarissen. (...) Gevolg is wel dat in toenemende mate strategische besluiten in grote internationale ondernemingen grotendeels aan de invloed van Nederlandse werknemers(vertegenwoordigers) zijn onttrokken. Daar staat maar in beperkte mate compensatie tegenover in de (beperkte) rechten van de Europese ondernemingsraad. ${ }^{\text {'2 }}$

Dit raakt een pijnlijk punt: als er tegenwoordig nauwelijks beursgenoteerde structuurvennootschappen zijn, wordt het doel dat met deze regeling werd nagestreefd dan nog wel behaald?

\section{Vennootschappelijke medezeggenschap: what's left?}

Met de herziening van de structuurregeling in 2004 is destijds beoogd een nieuw evenwicht tot stand te brengen tussen de belangen van werknemers enerzijds en

77 Zo ook M. Holtzer, De invloed van werknemers op de strategie van de vennootschap (diss. Groningen) 2014, Deventer: Kluwer 2014, p. 125.

78 M. Meyer, De positie van Nederlandse ondernemingsraden in internationale concerns: een pleidooi voor procesgerichte medezeggenschap, TRA 2016/45, par. 4.3.

79 Zie ook P. van Beurden, H. van Ees \& R. Goodijk, Gebruik, niet-gebruik of onderbenutting? Onderzoek naar de mogelijke onderbenutting van bevoegdheden en mogelijkheden door de (Centrale) Ondernemingsraad in grote Nederlandse ondernemingen, Rapport voor het ministerie van Sociale Zaken en Werkgelegenheid 2009, p. 93.

80 Meyer 2016, par. 4.1.

81 Holtzer 2014, p. 195.

82 SER-advies 08/01 inzake evenwichtig ondernemingsbestuur, p. 30. 
aandeelhouders anderzijds. ${ }^{83}$ De aangebrachte wijzigingen, en in het bijzonder de introductie van het (versterkte) aanbevelingsrecht, hebben ertoe geleid dat veel in Nederland gevestigde concerns de (al dan niet vrijwillige) toepassing van het structuurregime verlieten. ${ }^{84}$ In de plaats hiervoor hebben veel ondernemingen de 'Nederland-constructie' toegepast. ${ }^{85}$ Dit betreft de vrijwillige toepassing van de (verzwakte) structuurregeling op subholdingniveau. Hiertoe wordt binnen het concern een juridisch-organisatorische splitsing aanbracht, waardoor Nederlandse en buitenlandse dochtermaatschappijen in van elkaar te onderscheiden subholdings zijn ondergebracht. Houdster van de aandelen in deze subholdingmaatschappijen is de al dan niet naar Nederlands recht opgerichte moedermaatschappij. ${ }^{86}$ Omdat op de subholding boven de Nederlandse dochtermaatschappijen het (verzwakte) structuurregime van toepassing is, zijn alle overige Nederlandse groepsmaatschappijen vrijgesteld. ${ }^{87}$ De juridische toelaatbaarheid van deze constructie is in literatuur en rechtspraak onbestreden. ${ }^{88}$ Op basis van eerder kwantitatief onderzoek is vastgesteld dat van alle Nederlandse multinationale ondernemingen meer dan $30 \%$ van een dergelijke constructie gebruik maakt. In geval van buitenlandse ondernemingen die zich in Nederland hebben gevestigd, betreft dit meer dan $57 \% .^{89}$

Vanuit concernperspectief heeft deze juridisch-organisatorische splitsing tot gevolg dat de concernleiding zich niet meer hoeft te bekommeren over de operationele activiteiten; zij focust zich nu op de strategie van het concern als geheel. ${ }^{90}$ Vanuit het perspectief van medezeggenschap heeft een dergelijke wijziging in de structuur van het concern tot gevolg dat krachtens art. 33 lid 3 WOR de subholding als ondernemer wordt aangewezen tegenover de centrale ondernemings-

Dirks, van Hussen \& Soerjatin 2004, p. 21. Dit wordt ook duidelijk uit het grotendeels door de wetgever overgenomen advies van de SER over het functioneren en de toekomst van de structuurregeling van 19 januari 2001, p. 52 (SER-advies 01/02). Voor de positieve reactie op het advies, zie Kamerstukken II 2000/01, 25732, 18.

84 Direct na de aankondiging van de voorstellen werd duidelijk dat veel ondernemingen van de structuurregeling af wilden. De Nijs Bik merkt op dat dit waarschijnlijk werd ingegeven door de vrees voor het versterkte aanbevelingsrecht van de ondernemingsraad. Zie De Nijs Bik 2004, p. vii. O.a. bedrijven zoals ABN AMRO, Aegon en ING wijzigden nagenoeg onmiddellijk hun statuten. Zie daarvoor S-J. Spanjaard, Beëindiging structuurregime ING Groep, AEGON en ABN AMRO Holding, Ondernemingsrecht 2003/7, p. 266.

85 In het bijzonder verwijzen we naar: L.G. Verburg, Het territoir van de (Nederlandse) ondernemingsraad in het internationale bedrijfsleven (diss. Amsterdam UvA), Deventer: Kluwer 2007, p. 301; Holtzer 2014, p. 5. Deze problematiek wordt ook besproken in het SER-advies 08/01 en het kabinetstandpunt Medezeggenschap 2009 (Kamerstukken II 2009/10, 29818, 32). Zie verder K.J. Hopt, Labor representation on corporate boards: Impacts and problems for corporate governance and economic integration in Europa, International Review of Law and Economics 1994, afl. 14, p. 204.

86 De moederonderneming is niet onderworpen aan de structuurregeling omdat zij ofwel een buitenlandse rechtspersoon is, ofwel als Nederlandse vennootschap het karakter heeft van een internationale holding.

87 Art. 2:153/263 lid 3 BW. Zie ook Holtzer 2014, p. 78.

88 Verburg 2007, p. 310; Hof Amsterdam 16 februari 1989, NJ 1990/693 (COR/Douwe Egberts).

89 Holtzer 2014, p. 131; Meyer 2017, p. 136-137.

90 Verburg 2007, p. 306; Zaal 2014, par. 4.6. 
raad. ${ }^{91}$ Ook heeft dit tot gevolg dat het versterkte recht van aanbeveling geldt ten aanzien van de rvc van de subholding. Hierdoor heeft de hoogste ondernemingsraad binnen het concern geregeld niet meer het bestuur van de topholding als gesprekspartner, maar veelal de directie van de Nederlandse subholding. Het komt zelfs nog wel eens voor dat de hoogste ondernemingsraad binnen een multinationale onderneming een personeelsdirecteur als gesprekspartner moet dulden. ${ }^{92}$ In het verlengde hiervan wordt ook wel eens gesteld dat 'de subholding slechts fungeert als een doorgeefluik voor de beslissingen die de topholding neemt'. ${ }^{93}$

Of een centrale ondernemingsraad op subholdingniveau dus enige invloed heeft op de algehele koers van een onderneming is tevens afhankelijk van de eventuele informele invloed die het bestuur en de rvc van de subholding hebben op de concernleiding en haar rvc. ${ }^{94}$ In Nederland gevestigde internationale concerns bewegen zich derhalve langzamerhand volledig buiten het bereik van vennootschappelijke medezeggenschap door hun corporate governance in overeenstemming met de 'Nederland-constructie' in te richten. ${ }^{95}$ Dat belemmert de effectieve uitoefening van het versterkte recht van aanbeveling.

Het doel dat oorspronkelijk met de invoering van de structuurregeling werd nagestreefd, meer democratie en sterker toezicht binnen de grote onderneming, wordt vaak niet meer behaald. Enerzijds heeft deze vaststelling te maken met de aard van het concern zelf: gelaagde besluitvorming en daarbij behorende afbakeningsproblematiek voor medezeggenschap belemmeren de effectieve uitoefening van medezeggenschap. Anderzijds speelt het overkoepelende concernbelang, dat de besluitvorming van eventueel op het versterkte recht van aanbeveling geplaatste dochtercommissarissen beïnvloedt, een belangrijke rol. De systematiek van de structuurregeling zelf doet ook een duit in het zakje. In toenemende mate hoeven ondernemingen, al naar gelang zij internationaler worden, niet meer of slechts gedeeltelijk aan haar bepalingen toepassing te geven.

Het systeem van vrijstellingen bestaat mede doordat het niet billijk werd gevonden om louter aan de Nederlandse ondernemingsraad het (versterkte) recht van aanbeveling toe te kennen. Dat zou afbreuk doen aan de legitimiteit van de wettelijke regeling. Gevolg van deze gedachte is echter dat niet alleen de Nederlandse werknemers geen invloed meer uit kunnen oefenen aan de top van de onderneming, maar ook geen enkele werknemer van het concern nog formele

91 Bartman, Dorresteijn \& Olaerts 2016, p. 146.

92 Meyer 2016, p. 11. Zie ook R.H. van het Kaar, Evenwichtig ondernemingsbestuur: quo vadis?, SR 2007/78. Een voorbeeld uit rechtspraak waarin deze 'degradatie' van medezeggenschap door de ondernemingsraad wordt aangevochten betreft: Hof Amsterdam (OK) 16 februari 1989, NJ 1990/693 (Sara Lee DE).

93 Bosse 1984, p. 193.

94 Daarbij speelt bijvoorbeeld al mee of beide directies op hetzelfde kantoor gevestigd zijn. Zie ook Holtzer 2014, p. 128. Ook speelt bij deze vaststelling de verhouding tussen het concernbelang en het vennootschappelijk belang (van de dochtermaatschappij) een grote rol. 
medezeggenschap uit kan oefenen ten aanzien van de samenstelling van het toezicht op de concernleiding.

\section{Eindevaluatie}

Voor het onder druk staan van het genoemde uitgangspunt van vennootschappelijke medezeggenschap zijn goede redenen te noemen. De werking van het Nederlandse medezeggenschapsrecht is immers in territoriaal opzicht beperkt tot in Nederland gevestigde ondernemingen. Het is daarbij niet van belang of de onderneming in stand wordt gehouden door een Nederlandse of een buitenlandse ondernemer. ${ }^{96}$ De WOR kent ook een breed ondernemersbegrip en knoopt niet aan bij regels uit Boek 2 BW. ${ }^{97}$ Wegens de beperkte territoriale werking van de WOR vallen onderdelen van de arbeidsorganisatie buiten Nederland, dus in beginsel buiten het bereik van de Nederlandse medezeggenschap. Dat wordt duidelijk ingeval bijvoorbeeld een besluit wordt (voor)genomen tot vestiging, overneming of afstoten van zeggenschap over een andere onderneming in het buitenland (vgl. art. 25 lid 1 sub b WOR). De zogeheten buitenlandclausule van de WOR bepaalt dat hierover geen adviesrecht bestaat indien redelijkerwijs niet te verwachten is dat het besluit zal leiden tot adviesplichtige besluiten voor de Nederlandse onderneming zelf. ${ }^{98}$

De reden voor het beperkte territoir van de Nederlandse ondernemingsraad is gelegen in de noodzakelijk geachte legitimiteit van medezeggenschap. De gedachte om alleen aan werknemers in Nederland van een internationaal opererend concern vennootschappelijke medezeggenschap toe te kennen ten aanzien van het toezicht op de concernleiding - zoals in Duitsland het geval is - wordt verworpen met een beroep op dat legitimiteitsbeginsel. ${ }^{99}$ Een Nederlandse vertegenwoordiging van werknemers zou niet representatief genoeg zijn voor al het personeel, en 'zodoende over onvoldoende legitimiteit beschikken zich in te laten met de beslissingen die mede bepalend zijn voor het beleid in de buitenlandse ook HR 30 december 1994, NJ 1995/449 (UIC); Hof Amsterdam (OK) 21 december 2012, RO 2013/23 (VLM).

97 Art. 1 lid 1 sub c en d WOR. Zie Bartman, Dorresteijn \& Olaerts 2016, p. 135.

98 Art. 25 lid 1 laatste volzin WOR. Bartman, Dorresteijn en Olaerts (2016, p. 167) noemen als voorbeeld voor wanneer er wel sprake kan zijn van een dergelijk adviesplichtig besluit de situatie waarin een buitenlandse onderneming die op dezelfde markt opereert mogelijk overgenomen gaat worden door de ondernemer. Leerstukken zoals toerekening en medeondernemerschap spelen hier ook een rol, maar gaan het bestek van dit artikel te buiten. Wel verdient vermelding dat het door toerekening kan voorkomen dat bepaalde besluiten van de concernleiding adviesplichtig zijn, ongeacht de structuur van het concern (bijv. de 'Nederland-constructie'). Een voorbeeld hiervan betreft: HR 26 januari 1994, NJ 1994/545 (Heuga). Besluitvorming over de internationale strategie zelf valt echter buiten het bereik van de centrale ondernemingsraad: Hof Amsterdam 19 januari 2008, JOR 2008/8 (Packard Bell). Zie ook Verburg 2007, p. 157 e.v.

99 F.G. Laagland, De rol van Nederlandse werknemers(vertegenwoordigers) bij een grensoverschrijdende juridische fusie (diss. Nijmegen), Deventer: Kluwer 2013, par. 4.2.6.1. 
concernonderdelen' ${ }^{100}$ Om deze reden voorziet de structuurregeling onder andere in de vrijstelling voor de internationale (top)holding.

Duidelijk is evenwel ook dat het door het territorialiteitsbeginsel ingevulde legitimiteitsargument (achter vennootschappelijke medezeggenschap) niet goed aansluit op de almaar voortschrijdende internationalisering van het Nederlandse bedrijfsleven. ${ }^{101}$ Ons inziens zijn de beginselen van territorialiteit en legitimiteit sterke argumenten voor effectief nationaal medezeggenschapsrecht. Toch hebben zij in de afgelopen jaren een belangrijk gedeelte van hun overtuigingskracht verloren. Het is namelijk onbegrijpelijk dat aan de ene kant de werking van de structuurregeling als bijzonder waardevol wordt gezien, maar dat aan de andere kant een belangrijk gedeelte van de grote vennootschappen in Nederland aan haar bepalingen geen toepassing hoeft te geven. ${ }^{102}$ Toepassing van de structuurregeling lijkt tot willekeur verworden, nu internationale concerns vaak zelf kunnen kiezen hoe zij aan de bepalingen uit deze regeling toepassing geven. In hoeverre komt de al eerder genoemde gedachte binnen het Nederlandse (vennootschaps)recht, dat werknemers zich onder de belangrijkste stakeholders van de onderneming mogen scharen, nog terug in deze praktische toepassing van de structuurregeling?

Ons inziens is de gedachte achter vennootschappelijke medezeggenschap - invloed van werknemers op de top - zeker niet achterhaald. Haar vorm is echter aan vernieuwing toe, want de structuurregeling is niet meer in staat om hier op adequate wijze in te voorzien. Het territoir van de gemiddelde Nederlandse onderneming beperkt zich immers al lang niet meer tot de landsgrenzen. ${ }^{103}$ In hoeverre is het nog houdbaar om buitenlandse werknemers uit te sluiten van de uitoefening van (vennootschappelijke) medezeggenschap? Zijn zij niet ook, net zoals werknemers in Nederland, te scharen onder de belangrijkste stakeholders van de onderneming? Al duidelijk werd dat de Nederlandse wetgever de territoriale reikwijdte van de regeling bepaalt. Het staat hem derhalve vrij om ook buitenlandse werknemers in de uitoefening hiervan te betrekken.

Het moge in elk geval duidelijk zijn dat de verregaande internationalisering van het bedrijfsleven een van de grootste uitdagingen vormt voor de effectiviteit van de structuurregeling en vennootschappelijke medezeggenschap. Omdat de arbeidsrechtelijke regelingen in de verschillende wereldwijde jurisdicties dermate

100 Laagland 2013, par. 4.2.6.1; Zaal 2014, par. 5.3.3; Kamerstukken II 1969/70, 10751, 3, p. 14.

101 SER-advies 08/01; Asser/Maeijer \& Kroeze 2-I* 2015/609; Laagland 2013, par. 4.2.8. De SER onderschrijft de argumenten van territorialiteit en legitimiteit nog steeds, maar herkent tegelijkertijd de problematiek die samenhangt met medezeggenschap in internationale concernverhoudingen. Zie hiervoor de SER-notitie, Medezeggenschap in de 21e eeuw, juni 2012.

102 Zie M. Holtzer, De economische werkelijkheid bij strategiebepaling, ArbeidsRecht 2015/9, par. 1, waarin nogmaals wordt stilgestaan bij de vaststelling dat het wetgevingsproces rondom medezeggenschap 'muurvast' lijkt te zitten. Wij wijzen er ook op dat multinationale ondernemingen goed zijn voor ruim anderhalf miljoen voltijdsbanen op de Nederlandse arbeidsmarkt (CBS, Internationaliseringmonitor (vierde kwartaal 2017), p. 72).

103 Laagland 2013, par. 4.2.7. 
verschillend zijn, is het zelfs al lastig om daarin gemeenschappelijke kenmerken te ontwaren. ${ }^{104}$ Het is dan ook weinig zinvol om over een wereldwijd medezeggenschapsrecht na te denken. ${ }^{105}$

Een veelgehoord tegenargument ten aanzien van een sterker vennootschappelijk medezeggenschapsrecht betreft het behouden van een gunstig vestigingsklimaat, maar men kan zich afvragen of het stelsel van medezeggenschapsrecht daadwerkelijk de doorslag geeft ten opzichte van bijvoorbeeld economische, fiscale of infrastructurele motieven voor een internationaal concern om zich in Nederland te vestigen. ${ }^{106}$ Munkholm zegt er het volgende over:

'The scholarly debate on corporate governance revolves around economic cost/benefit models, where the issue at company level is whether employee representation yields more economic benefits than the costs of such representation, and the issue at national level is whether employee representation is an element detrimental to the competitiveness of the national companies. ${ }^{107}$

Alhoewel de vragen uit dit citaat niet eenvoudig zijn te beantwoorden, zijn er indicaties dat de uitkomst niet per se ten nadele van vennootschappelijke medezeggenschap hoeft uit te vallen. ${ }^{108}$ Vermelding verdient verder, anders dan bijvoorbeeld in Duitsland, dat Nederlandse vennootschappelijke medezeggenschap zich kenmerkt door de onafhankelijkheid van commissarissen. Een door werknemers aanbevolen commissaris is derhalve niet het verlengstuk van de factor arbeid binnen de rvc. Zij draagt echter wel bij aan het tegemoetkomen aan de behoefte van vennootschappelijke medezeggenschap bij werknemers, en aan transparanter toezicht. Daarmee is de vennootschappelijke medezeggenschap lang niet zo verstrekkend als in Duitsland het geval is.

Naar onze mening zou een concern dat zich wenst te vestigen in Nederland of zich hier reeds heeft gevestigd, moeten accepteren dat het onderworpen zal zijn aan een vorm van vennootschappelijke medezeggenschap. Dat is immers een historisch gegroeid onderdeel van onze werknemerscultuur en past goed in ons stakeholdersmodel. Bovendien is vennootschappelijke medezeggenschap binnen

104 Holtzer 2014, p. 203.

105 Holtzer 2014, p. 203; Verburg 2007, p. 256.

106 Van het Kaar 2009, par. 5.

107 Zie N.V. Munkholm, Board level employee representation in Europe: An overview. A Thematic Working Paper for the Annual Conference of the European Centre of Expertise (ECE) in the field of labour law, employment and labour market policies: 'Perspectives of collective rights in Europe', maart 2018, p. 9, geraadpleegd op 11 januari 2019 via: https://eu.eventscloud.com/file_ uploads/e0bd9a01e363e66c18f92cf50aa88485_Munkholm_Final_EN.pdf.

108 Zie G. Jackson, Employee representation in the board compared: A fuzzy-sets analysis of corporate governance, unionism and political institutions, Industrielle Beziehungen (The German Journal of Industrial Relations) (12) 2005, afl. 3, p. 2. Zie voorts J. Forth, A. Bryson \& A. George, Explaining cross-national variation in workplace employee representation, Discussion Paper nr. 9963, mei 2016 p. 20. 
Europa niet heel bijzonder en komt zij relatief vaak voor. ${ }^{109}$ Wij beseffen overigens goed dat over vennootschappelijke medezeggenschap door sommigen - bijvoorbeeld Amerikaanse investeerders - heel anders wordt gedacht. ${ }^{110}$

Duidelijk bleek al dat het oorspronkelijke doel van de structuurregeling, invloed op de top, tegenwoordig niet meer voldoende gerealiseerd wordt. Toepassing van de regeling is verworden tot willekeur. Als wij de structuurregeling nog willen handhaven, en weer willen laten aansluiten op de oorspronkelijke ratio achter de regeling, dan dient zij te worden aangepast. Struisvogelpolitiek door de kop in het zand te blijven steken lijkt ons in elk geval geen zinvolle voortzeting. Het volgende zou overwogen kunnen worden:

1 Het schrappen van de internationale holdingvrijstelling in de structuurregeling en daarmee gepaard gaande de formulering van een regeling voor het betrekken van buitenlandse werknemers bij de uitoefening van deze vennootschappelijke medezeggenschap. Om dit in het licht van het behouden van een positief vestigingsklimaat minder bezwaarlijk te maken, kan gedacht worden aan een advies- of consultatierecht voor de centrale ondernemingsraad of, indien hij is ingesteld, de Europese ondernemingsraad (EOR). ${ }^{111}$ Hiermee begeeft de vennootschappelijke medezeggenschap zich weer naar de top van de onderneming, en neemt zij tevens de bezwaren vanuit het legitimiteitsperspectief voor een belangrijk deel weg.

2 Het opleggen van het verzwakte regime op de internationale holding met zetel in Nederland.

3 De Richtlijn EOR is een minimumrichtlijn. ${ }^{112}$ In de Wet op de Europese ondernemingsraden (WEOR) kunnen derhalve aanvullende bepalingen worden opgenomen die het verplicht stellen om met de bijzondere onderhandelingsgroep over een medezeggenschapsregeling tot overeenstemming te komen. Hierdoor kan bijvoorbeeld aan de EOR de bevoegdheid toekomen (of het recht om kandidaten aan te bevelen) om geconsulteerd te worden over de samenstelling van de rvc. Vastgelegd zou kunnen worden dat indien een dergelijke medezeggenschapsregeling is getroffen, de verplichte toepassing van het structuurregime op subholdingniveau vervalt.

4 De invoering van een wettelijke regeling voor contractuele vormen van grensoverschrijdende vennootschappelijke medezeggenschap in internationaal concernverband binnen de systematiek van de structuurregeling. Daarmee wordt bevorderd dat internationale concerns kiezen voor het betrekken van al hun werknemers bij het uitoefenen van vennootschappelijke medezeggen-

109 In Denemarken, Duitsland, Finland, Frankrijk, Hongarije, Luxemburg, Kroatië, Nederland, Noorwegen, Oostenrijk, Slovenië, Slowakije, Tsjechië en Zweden kent men wettelijke regelingen ter zake van vennootschappelijke medezeggenschap. Zie Munkholm 2018, p. 5-6. Zie ook Jackson 2005, p. 4-5.

110 Zo is door Van den Ingh zelfs gepleit voor afschaffing van de structuurregeling, mede omdat de WOR al voldoende invloed geeft. Zie F.J.P. van den Ingh, Requiem voor de structuurregeling. Het verdriet van Den Haag, Ondernemingsrecht 2001/8.

111 Zie ook Verburg 2007, p. 399.

112 Laagland 2013, par. 7.3.1. 
schap. Gevolg van het toepassen van een dergelijke vorm van contractuele medezeggenschap zou voor het concern met zich mee kunnen brengen dat de in Nederland gevestigde groepsmaatschappijen vrijgesteld zijn van toepassing van de structuurregeling. Hiermee zouden niet alleen Europese werknemers, maar ook werknemers daarbuiten binnen het bereik van vennootschappelijke medezeggenschap kunnen worden gebracht. De vraag blijft of internationale concerns hierin meegaan, maar betoogd kan worden dat de vrijstelling van de structuurregeling zou kunnen leiden tot een verhoogde aantrekkingskracht van een dergelijke vorm voor grensoverschrijdende medezeggenschap. Het verdient in ieder geval de voorkeur ten opzichte van de huidige 'nulsituatie: geen medezeggenschap op het hoogste niveau'. ${ }^{113}$

\section{Conclusie}

Onderzoek wijst uit dat er nauwelijks nog beursgenoteerde structuurvennootschappen zijn. Dit mag verwonderlijk worden genoemd, nu de structuurregeling juist een bijzonder juridisch samenstel van regels voor grote vennootschappen is. Het is ons inziens hoog tijd dat de Nederlandse wetgever de gevolgen van internationalisering, en het daardoor ontstane 'bedrijfsdemocratisch tekort', ${ }^{114}$ voor de uitoefening van vennootschappelijke medezeggenschap in ogenschouw neemt en overgaat tot aanpak van de huidige achterhaalde structuurregeling. Wij hebben hiervoor alvast enkele suggesties gedaan.

113 Van het Kaar 2009, par. 2 en 5.

114 P.F. van der Heijden, Westenwind, Amsterdam: Balans 2004, p. 76. 